\title{
Use of Untreated and Autoclave-Treated Wheat Germ Meal in Growing Rabbit Diets
}

\author{
Walaa Attia Salama", Amira Mahmoud Refaie, Hamdy Farouk Amin and Lamiaa Fathy Abdel-Mawla \\ Animal Production Research Institute, Agricultural Research Center, Giza, Egypt. \\ "Corresponding author's Email: dr.walaa..attia@gmail.com; ORCID: 0000-0002-1854-1986
}

\begin{abstract}
The present study was intended to investigate the influence of using $20 \%$ and $40 \%$ treated or untreated wheat germ meal in growing New Zealand rabbit diets. A total of 75 weaned New Zealand White rabbits aged six weeks old, with an average initial weight of $659.60 \pm 18.84 \mathrm{~g}$ were divided into five groups with five replicates in each group (three rabbits per replicate). The first group was fed on a basal diet $\left(\mathrm{T}_{1}\right)$, second and third groups received diets containing Wheat Germ Meal (WGM), as replacement of soybean meal protein, at levels of $20 \%$ and $40 \%$ and were labeled as $\mathrm{T}_{2}, \mathrm{~T}_{3}$, respectively. Fourth and fifth groups were fed with $20 \%$ and $40 \%$ autoclave-treated WGM ( $\mathrm{T}_{4}$ and $\mathrm{T}_{5}$, respectively). The trial was continued until 14 weeks of age. The present study was evaluated growth performance, blood parameters, carcass traits, meat quality in different groups and also economic efficiency was calculated. There were insignificant differences in terms of live weight, daily weight gain, carcass weight and dressing percentages among rabbits in groups of $T_{1}, T_{2}$, and $T_{4}$. Rabbits in the group of $\mathrm{T}_{4}$ achieved the best feed conversion ratio. Digestion coefficients of crude protein, crude fiber, ether extract, nitrogen-free extract, and nutritive value in terms of digestible crude protein, total digestible nutrition, and digestible energy did not significantly differ between $T_{1}$ and $T_{4}$. However, these factors significantly decreased in $\mathrm{T} 3$ and $\mathrm{T}_{5}$ compared to $\mathrm{T}_{1}$. Plasma total protein and globulin significantly increased in rabbits of $\mathrm{T}_{2}$ and $\mathrm{T}_{4}$ compared to those fed in $\mathrm{T}_{1}$ group. A significant decrease in total cholesterol and total lipid for rabbits in groups of $\mathrm{T}_{4}$, $\mathrm{T}_{5}$, and $\mathrm{T}_{2}$ was observed. Moreover, rabbits fed on $\mathrm{T}_{4}$ or $\mathrm{T}_{2}$ diets had the highest economic efficiency. Conclusively, the untreated or autoclaved WGM can be used in growing rabbit diets up to $20 \%$ for replacing the soybean meal protein, which caused low feed costs without adverse effects on the growth performance of rabbits.
\end{abstract}

Key words: Rabbits, Soybean meal, Wheat germ meal

\section{INTRODUCTION}

Wheat, maize, rice, oats, barley, millets, sorghum, and rye are important cereals for human nutrition, either for cooking or as raw material for obtaining flour for baking (De Vasconcelos et al., 2013). Wheat is one of the important cereals and food ingredients around the world due to its ability to be converted to flour. Wheat flour is produced by milling wheat and extraction rate varies from $73 \%$ to $77 \%$, depending on the variety of wheat and the production conditions (Elliott et al., 2002). Therefore, in the milling process, by-products such as wheat germ, wheat bran and parts of the endosperm comprise 23 to $27 \%$ of the production.

The wheat germ as a significant by-product of the cereal industry accounts for 2.5 to $3.8 \%$ of the total grain weight (Brandolini and Hidalgo, 2012). The wheat germ oil is the richest natural source of vitamin E ( $\alpha$-tocopherol) (Gerald et al., 2017). Hafez et al. (2019) found that rats received $3 \mathrm{~g} / \mathrm{kg}$ wheat germ oil had a non-significant increase in Malondialdehyde (MDA) levels of serum at the $15^{\text {th }}$ day of study as compared to control group. Saleh (2016) found that oral administration of wheat germ oil $(1400 \mathrm{mgkg})$ to mice for eight days improved the liver and small intestine damage induced by carbon tetrachloride.

The Wheat Germ Meal (WGM) is produced when the oil is extracted from the wheat germ. WGM is high in protein content and rich in carbohydrates which could be processed further into livestock feeds. WGM as a good source of water-soluble vitamins also has a high content of lysine, threonine, and histidine (Barton and Monr, 1946). In addition, Moran and Summers (1967) reported that WGM contains 29\% Crude Protein (CP), 2.1\% Crude Fiber (CF), 10.3\% Ether Extract (EE). Moreover, it contains gluten and antinutritional factors such as hemagglutinins and trypsin inhibitor, which inhibit enzymatic digestion of proteins (Creek and Vasaitis, 1962). Therefore, methods such as autoclaving or biological treatment are essential for improving the nutritive value of WGM. Autoclaving destroys the activity of these factors (Creek et al., 1962). Moran and Summers (1967) demonstrated the Autoclaved Wheat Germ Meal (AWGM) at $121{ }^{\circ} \mathrm{C}$ for 20 minutes, incorporated to chicken diets at the level of either $47 \%$ or $63.8 \%$ improve growth performance and feed utilization compared to groups fed WGM autoclaved for $90 \mathrm{~min}$ and control group. Hence, the objective of the present 
study was to investigate the effects of partial replacement of soybean meal protein with autoclave treated WGM protein on feed cost and growth performance of rabbits.

\section{MATERIALS AND METHODS}

The experiments were conducted at Borg-El Arab, located in Alexandria governorate, Egypt. The autoclave treatments were performed at the laboratories of By-Products Research Department, Animal Production Research Institute, Agriculture Research Center, Giza, Egypt.

\section{Ethical approval}

The study was carried out after obtaining the ethical approval from the Animal Production Research Institute, Egypt.

\section{Wheat germ meal processing}

WGM was obtained from the processing and extraction unit of natural oils, National Research Center, Giza, Egypt. It was ground by a hammer mill and stored in an air-tight condition then kept for further processing.

\section{Autoclave treatment}

WGM was treated with an autoclave at $121^{\circ} \mathrm{C}$ for 20 minutes as recommended by Moran and Summers (1967). After treatment of the WGM, the drying was done in the air for $10 \mathrm{~min}$ and then kept for chemical analysis before mixing to the diets. Dry gluten content was determined according to Haraszi et al. (2011) and trypsin inhibitor activity was assessed as defined by Makkar et al. (2008). These measurements were performed before and after treatment.

\section{Animal management and feeding}

Seventy-five weaned New Zealand White rabbits of both sexes (six weeks old, the average body weight of $659.60 \pm 18.84 \mathrm{~g}$ ) were allocated to five dietary treatments of 15 rabbits per treatment. Each treatment was replicated 5 times (three rabbits per replicate). The $\mathrm{T}_{1}$ was fed the control diet, the $\mathrm{T} 2$ and $\mathrm{T} 3$ received $20 \%$ and $40 \%$ untreated WGM in replacing of soybean meal protein, respectively (6.12 and $12.31 \%$ of the whole diet, respectively). The T4 and T5 were fed on $20 \%$ and $40 \%$ autoclavetreated WGM, which consisted of 6.20 and $12.41 \%$ the whole diet, respectively. The ingredients and chemical composition of diets are presented in table 1. All the experimental diets were formulated to be isonitrogenous and isocaloric, to meet all the essential nutrient requirements of growing rabbits according to (Egyptian Agriculture Ministry Decree, 1996). The animals were reared in metal battery cages equipped with separated feeders and automatic nipple drinkers. All animals were receiving control diet for one week before the start of the experimental period and vaccinated against diseases during the veterinary examinations. Feed and water were offered ad libitum. The management and hygienic conditions were identical for all groups.

Table 1. Ingredients and chemical composition of experimental diets

\begin{tabular}{|c|c|c|c|c|c|}
\hline Ingredients (\%) & $\mathbf{T}_{1}$ & $\mathbf{T}_{2}$ & $\mathbf{T}_{3}$ & $\mathbf{T}_{4}$ & $\mathbf{T}_{5}$ \\
\hline Barley & 30.26 & 27.48 & 25.93 & 27.48 & 25.83 \\
\hline Clover hay & 26.74 & 27.05 & 26.05 & 27.05 & 26.05 \\
\hline Wheat bran & 18.40 & 18.40 & 18.40 & 18.40 & 18.40 \\
\hline Soybean meal (44\%) & 18.10 & 14.47 & 10.86 & 14.47 & 10.86 \\
\hline Wheat germ meal & -- & 6.15 & 12.31 & 6.20 & 12.41 \\
\hline Molasses & 3.00 & 3.00 & 3.00 & 3.00 & 3.00 \\
\hline Di calcium phosphate & 2.20 & 2.20 & 2.25 & 2.20 & 2.25 \\
\hline Sodium chloride $(\mathrm{NaCl})$ & 0.30 & 0.30 & 0.30 & 0.30 & 0.30 \\
\hline Vit.\& min. $\operatorname{mix}^{1}$ & 0.30 & 0.30 & 0.30 & 0.30 & 0.30 \\
\hline Lime stone & 0.35 & 0.35 & 0.35 & 0.35 & 0.35 \\
\hline DL-Methionine & 0.30 & 0.25 & 0.20 & 0.25 & 0.20 \\
\hline Anticoccidia (Diclazuril) & 0.05 & 0.05 & 0.05 & 0.05 & 0.05 \\
\hline Total & 100 & 100 & 100 & 100 & 100 \\
\hline \multicolumn{6}{|l|}{ Chemical analysis ${ }^{2}$} \\
\hline Crude protein (\%) & 17.70 & 17.37 & 17.04 & 17.36 & 17.06 \\
\hline Crude fiber (\%) & 12.87 & 12.64 & 12.08 & 12.65 & 12.08 \\
\hline Ether extract (\%) & 2.17 & 2.44 & 2.70 & 2.39 & 2.70 \\
\hline Nitrogen-free extract (\%) & 59.22 & 59.88 & 58.98 & 58.39 & 59.16 \\
\hline Digestible Energy $(\mathrm{kcal} / / \mathrm{kg})$ & 2533.35 & 2515.5 & 2512.5 & 2515.6 & 2512.4 \\
\hline Methionine+ cysteine $(\%)$ & 0.55 & 0.54 & 0.54 & 0.54 & 0.54 \\
\hline Lysine $(\%)$ & 0.91 & 1.10 & 1.28 & 1.09 & 1.28 \\
\hline
\end{tabular}




\section{Experimental parameters}

\section{Growth performance}

Feed Intake (FI, g/ rabbit/ day) and Body Weight Gain (BWG, g/ rabbit/ day) were recorded weekly. Moreover, the Feed Conversion Ratio (FCR) was calculated as F//BWG over an experimental period of 8 weeks.

\section{Digestion trial}

Digestibility test was carried out using five male rabbits from each experimental group in the last week of the experiment (14 weeks of age). The feces were daily collected separately for six days. The feces were sprayed with $2 \%$ boric acid solution for trapping released ammonia and dried at $60^{\circ} \mathrm{C}$ for 48 hours (until constant weight). Feces were ground and stored for subsequent chemical analysis. Samples of WGM, diets, and feces were analyzed for moisture, ash, Nitrogen-Free Extract (NFE), EE, CF, and CP according to AOAC (2000).

\section{Carcass traits}

At 14 weeks of age, 25 rabbits (five rabbits per treatment) were slaughter to determine carcass traits according to Biasco and Ouhayoun (1996).

\section{Chemical meat measurement}

Longissimus dorsi muscles from 25 samples were frozen at $-20{ }^{\circ} \mathrm{C}$ for determination of total cholesterol, MDA and Total Antioxidant Capacity (TAOC) by colorimetric methods using analytical kits (Bio Diagnostic Company, Egypt)

\section{Blood parameters}

Blood samples were taken from the five rabbits per treatment at the time of slaughter and were collected in dry clean tubes containing heparin and centrifuged at $3000 \mathrm{rpm}$ for 20 minutes. Then plasma was separated and stored in a deep freezer at approximately $-20^{\circ} \mathrm{C}$ till the time for determining total lipids, total cholesterol, total protein, and albumin. Aspartate Aminotransferase (AST) and Alanine Aminotransferase (ALT) were colorimetrically determined using commercial kits, according to the manufacturer's instruction (purchased from Bio Diagnostic, Cairo, Egypt). The concentration of globulin (g/ $\mathrm{dl}$ ) was calculated by subtracting albumin from total protein values.

\section{Statistical analysis}

The experimental data were subjected to using analysis of variance (ANOVA) in the general linear model using SAS version 9 (SAS Institute Inc.) by the following model:

$\mathrm{Y}_{\mathrm{ij}}=\mu+\mathrm{T}_{\mathrm{i}}+\mathrm{e}_{\mathrm{ij}}$

Where $\mu$ was overall mean of $Y_{i j ;} T$ was the effect of treatment; i was $\left(1,2 \ldots\right.$, etc.), and $e_{i j}$ was experimental error. The Significant differences between treatments means were separated by Duncan's multiple range test (1955).

\section{Economic efficiency}

Economic efficiency was calculated using the following equation: Economic efficiency $=$ Net revenue $/$ total costs

Total cost was calculated in Egyptian pound according to the price at the time of the experiment.

\section{RESULTS}

\section{Chemical composition}

Chemical analysis of WGM and AWGM in comparison to soybean meal are shown in table 2. The CP was higher in soybean meal (44 \%) compared to WGM $(25.83 \%)$ and AWGM (25.62\%). Also, the CF was higher in soybean meal (7.3\%) compared to WGM (1.28 \%) and AWGM (1.22\%). However, the EE of soybean meal was lower (1.50\%) in comparison to WGM (6.02\%) and AWGM (5.30\%). On the other hand, DE of soybean meal was $3200 \mathrm{kcal} / \mathrm{kg}$ closed with WGM $(2900 \mathrm{kcal} / \mathrm{kg})$ and AWGM $(2901 \mathrm{kcal} / \mathrm{kg})$. WGM contained $4 \%$ dry gluten and trypsin inhibitor activity was $2.817 \mathrm{mg} / \mathrm{g}$, while autoclave treatment reduced dry gluten by $50 \%$ and trypsin inhibitor activity by $62.4 \%$ compared to WGM.

\section{Growth performance}

The results of final body weight, daily BWG, FI, and FCR are presented in table 3. Rabbits fed either $T_{1}$ or $T_{4}$ showed significantly higher final body weight followed by group fed $T_{2}$ compared to $T_{3}$ and $T_{5}$. While groups fed $T_{3}$ and $T_{5}$ had the lowest values. Rabbits fed control diet and $T_{4}$ recorded insignificantly higher BWG compared to $T_{2}$ and $T_{5}$. While the lowest values were recorded for $\mathrm{T}_{3}$. The FI was not significantly affected by any of the tested diets. Regarding FCR, the group fed $\mathrm{T}_{4}$ recorded the higher value without significant differences with $T_{1}$ group. Whereas, the lowest values were found in groups fed $T_{3}$ and $T_{5}$. 
Table 2. Chemical analysis of soybean meal, wheat germ meal and autoclave-treated wheat germ meal based on dry matter percentage

\begin{tabular}{lccc}
\hline Items & Soybean meal* & WGM & AWGM \\
\hline Organic matter (\%) & 93.50 & 93.40 & 93.48 \\
Crude protein (\%) & 44.00 & 25.83 & 25.62 \\
Crude fiber (\%) & 7.30 & 1.28 & 1.22 \\
Ether extract (\%) & 1.50 & 6.02 & 5.30 \\
Nitrogen-free extract (\%) & 40.7 & 60.27 & 61.34 \\
Ash (\%) & 6.50 & 6.60 & 6.52 \\
Digestible energy** (Kcal/kg) & 3200 & 2900 & 2901 \\
Anti-nutritional factors & & 4.00 & 2.00 \\
$\quad$ Dry gluten (\%) & - & 2.817 & 1.058 \\
$\quad$ Trypsin inhibitor activity (mg/g) & 21.00 & & 2 \\
WGM: Wheat Germ Meal, AWGM: Autoclave-treated Wheat Germ Meal. *Chemical analysis according to Feed composition for animal and poultry
\end{tabular}
feedstuff used in Egypt (2001). **Digestible energy calculation was performed according to (Cheeke, 1987).

Table 3. Growth performance of New Zealand White rabbits (six weeks old) fed diets containing untreated or treated wheat germ meal

\begin{tabular}{lcccccc}
\hline Items & $\mathbf{T}_{\mathbf{1}}$ & $\mathbf{T}_{\mathbf{2}}$ & $\mathbf{T}_{\mathbf{3}}$ & $\mathbf{T}_{\mathbf{4}}$ & $\mathbf{T}_{\mathbf{5}}$ & $\mathbf{S E M}$ \\
\hline Initial body weight $(\mathrm{g})$ & 645.00 & 668.00 & 671.00 & 641.00 & 673.00 & 18.84 \\
Final body weight $(\mathrm{g})$ & $2143.3^{\mathrm{a}}$ & $2031.7^{\mathrm{ab}}$ & $1872.0^{\mathrm{c}}$ & $2108.0^{\mathrm{a}}$ & $1965.0^{\mathrm{bc}}$ & 30.56 \\
Daily body weight gain (g) & $26.76^{\mathrm{a}}$ & $24.35^{\mathrm{ab}}$ & $21.44^{\mathrm{b}}$ & $26.20^{\mathrm{a}}$ & $23.07^{\mathrm{ab}}$ & 0.70 \\
Daily feed intake (g) & 103.59 & 94.59 & 94.27 & 99.33 & 95.00 & 3.80 \\
Feed conversion ratio (g feed/g gain) & $3.87^{\mathrm{bc}}$ & $3.88^{\mathrm{bc}}$ & $4.39^{\mathrm{a}}$ & $3.79^{\mathrm{c}}$ & $4.11^{\mathrm{ab}}$ & 0.10 \\
\hline
\end{tabular}

Different superscript letters within the same row mean significant differences $(\mathrm{P}<0.05) . \mathrm{T}_{1}$ : control diet, $\mathrm{T}_{2:} 20 \%$ untreated wheat germ meal, $\mathrm{T}_{3}: 40 \%$ untreated wheat germ meal, $\mathrm{T}_{4}: 20 \%$ autoclave-treated wheat germ meal, $\mathrm{T}_{5}: 40 \%$ autoclave-treated wheat germ meal. SEM: Standard error of the mean.

\section{Digestion coefficient}

According to results shown in table 4, AWGM increased nutritive values for the rabbit compared with $40 \%$ untreated WGM. These results indicated that CP digestibility was significantly higher in $\mathrm{T}_{1}$ and $\mathrm{T}_{4}$ groups in comparison to other groups. Digestibility of $C F$, EE, and NFE were significantly improved in $T_{1}, T_{2}$, and $T_{4}$. Digestible CP values were significantly increased in $\mathrm{T}_{1}$ and the lowest values were found with inculcation untreated or treated WGM at the level of $40 \%$. Feeding with $\mathrm{T}_{4}$ and $\mathrm{T}_{1}$ diets enhanced total digestible nutrients, digestible crude protein and digestible energy compared to other treatments.

\section{Carcass characteristics}

The results of carcass characteristics are presented in table 5. Carcass and dressing percentage were significantly higher in $\mathrm{T}_{1}, \mathrm{~T}_{2}$, and $\mathrm{T}_{4}$ in comparison to other groups. While $\mathrm{T}_{3}$ and $\mathrm{T}_{5}$ were significantly decreased in the carcass weight and dressing percentage compared to $T_{1}$. However, the percentage of liver, kidney, heart, and giblets were not significantly affected by any treatments.

\section{Meat quality}

Table 6 shows that the $T_{1}$ and $T_{5}$ recorded the highest TAOC value values in rabbit meat followed by $T_{2}$ and the lowest values were recorded for $\mathrm{T}_{3}$ and $\mathrm{T}_{4}$. The highest MDA value was recorded for $\mathrm{T}_{2}$ followed by $\mathrm{T}_{5}$. While $\mathrm{T}_{1}$ group was found to have the lowest value. Regarding total cholesterol in rabbit meat, $\mathrm{T}_{2}$ recorded significantly the highest level. The lowest level was found in the groups of $\mathrm{T}_{5}$ and $\mathrm{T}_{3}$.

\section{Blood constituents}

The plasma concentration of total protein, albumin, globulin, total cholesterol, and lipids are shown in table 7 . The obtained values of blood parameters were within the normal range. Insignificant differences were found in the concentration of plasma albumin, ALT and AST in different tested treatments. Plasma total protein increased significantly in $\mathrm{T}_{2}$ and $\mathrm{T}_{4}$ compared to control and $\mathrm{T}_{5}$ groups. Globulin values were significantly higher in rabbits fed $\mathrm{T}_{2}$ and $\mathrm{T}_{4}$ compared to other groups. The concentration of total cholesterol and lipid in plasma were significantly higher in $\mathrm{T}_{1}$ and $\mathrm{T}_{3}$ compared to control group.

\section{Economic efficiency}

Effects of replacement of treated or untreated WGM on economic efficiency are shown in table 8. The results indicated that inclusion 20 or $40 \%$ treated or untreated WGM decreased total feed cost /rabbit as a result of decreasing FI compared to control group. Growing rabbits fed diets either $\mathrm{T}_{4}$ or $\mathrm{T}_{2}$ recorded high economic efficiency followed by $\mathrm{T}_{1}$. Also, selling price increased in $\mathrm{T}_{4}$ than control (71.88 and 73.40 LE, respectively). The same trend was found in relative economic, where the best values were recorded in $\mathrm{T}_{4}$ and $\mathrm{T}_{2}$ groups (109.19 and $105.6 \%$, respectively), while the poorest value was recorded in $\mathrm{T}_{3}$ group. 
Table 4. Digestion coefficient of New Zealand White rabbits (six weeks old) fed on autoclave-treated or untreated wheat germ meal.

\begin{tabular}{|c|c|c|c|c|c|c|}
\hline Items & $\mathbf{T}_{1}$ & $\mathbf{T}_{2}$ & $\mathbf{T}_{3}$ & $\mathbf{T}_{4}$ & $\mathbf{T}_{5}$ & SEM \\
\hline Organic matter $(\%)$ & 64.05 & 60.60 & 58.67 & 61.44 & 58.81 & 1.18 \\
\hline Crude protein $(\%)$ & $74.31^{\mathrm{a}}$ & $65.94^{\mathrm{b}}$ & $60.67^{b}$ & $71.80^{\mathrm{a}}$ & $61.34^{\mathrm{b}}$ & 1.62 \\
\hline Crude fiber $(\%)$ & $40.85^{\mathrm{a}}$ & $33.99^{\mathrm{ab}}$ & $27.18^{\mathrm{b}}$ & $42.39^{\mathrm{a}}$ & $30.75^{\mathrm{b}}$ & 1.80 \\
\hline Ether extract (\%) & $80.77^{\mathrm{a}}$ & $77.09^{\mathrm{ab}}$ & $68.27^{\mathrm{c}}$ & $78.15^{\mathrm{ab}}$ & $73.82^{\mathrm{bc}}$ & 1.33 \\
\hline Nitrogen-free extract (\%) & $76.89^{\mathrm{a}}$ & $72.79^{\mathrm{ab}}$ & $68.68^{\mathrm{b}}$ & $75.41^{\mathrm{a}}$ & $71.73^{\mathrm{ab}}$ & 0.96 \\
\hline Digestible crude protein $(\%)$ & $13.15^{\mathrm{a}}$ & $11.37^{\mathrm{ab}}$ & $10.33^{\mathrm{b}}$ & $12.46^{\mathrm{a}}$ & $10.46^{\mathrm{b}}$ & 0.41 \\
\hline Total digestible nutrients $(\%)$ & $58.33^{\mathrm{a}}$ & $54.61^{\mathrm{b}}$ & $48.80^{\mathrm{c}}$ & $57.00^{\mathrm{ab}}$ & $50.66^{\mathrm{c}}$ & 1.03 \\
\hline Digestible energy $*(\mathrm{kcal} / \mathrm{kg})$ & $2584.01^{\mathrm{a}}$ & $2419.22^{\mathrm{b}}$ & $2161.84^{\mathrm{c}}$ & $2525.1^{\mathrm{ab}}$ & $2244.23^{\mathrm{c}}$ & 45.59 \\
\hline
\end{tabular}

$\mathrm{T}_{1}$ : control diet, $\mathrm{T}_{2:} 20 \%$ untreated wheat germ meal, $\mathrm{T}_{3}: 40 \%$ untreated wheat germ meal, $\mathrm{T}_{4}: 20 \%$ autoclave-treated wheat germ meal, $\mathrm{T}_{5}: 40 \%$ autoclave-treated wheat germ meal. SEM: Standard error of the mean. Different superscript letters within the same row mean significant differences $(\mathrm{p}<0.05)$. * Digestible energy $=$ Total digestible nutrients* 44.3, according to Schneider and Flatt (1975).

Table 5. Carcass traits of New Zealand White rabbits (six weeks old) fed on autoclave-treated or untreated Wheat germ meal

\begin{tabular}{|c|c|c|c|c|c|c|}
\hline Items & $\mathbf{T}_{1}$ & $\mathbf{T}_{2}$ & $\mathbf{T}_{3}$ & $\mathbf{T}_{4}$ & $\mathbf{T}_{\mathbf{5}}$ & SEM \\
\hline Carcass weight (\%) & $56.69^{\mathrm{a}}$ & $55.43^{\mathrm{a}}$ & $53.29^{\mathrm{b}}$ & $55.69^{\mathrm{a}}$ & $53.74^{\mathrm{b}}$ & 0.37 \\
\hline Dressing $(\%)$ & $60.38^{\mathrm{a}}$ & $58.89^{\mathrm{ab}}$ & $56.80^{c}$ & $59.52^{\mathrm{a}}$ & $57.59^{\mathrm{bc}}$ & 0.39 \\
\hline Liver $(\%)$ & 2.91 & 2.42 & 2.60 & 2.91 & 2.89 & 0.09 \\
\hline Heart $(\%)$ & 0.275 & 0.293 & 0.269 & 0.273 & 0.267 & 0.01 \\
\hline Spleen $(\%)$ & 0.035 & 0.048 & 0.055 & 0.036 & 0.053 & 0.003 \\
\hline Kidney (\%) & 0.706 & 0.705 & 0.588 & 0.614 & 0.645 & 0.01 \\
\hline Giblets (\%) & 3.69 & 3.46 & 3.51 & 3.83 & 3.85 & 0.08 \\
\hline
\end{tabular}

$\mathrm{T}_{1}$ : control diet, $\mathrm{T}_{2:}: 20 \%$ untreated wheat germ meal, $\mathrm{T}_{3}: 40 \%$ untreated wheat germ meal, $\mathrm{T}_{4}: 20 \%$ autoclave-treated wheat germ meal, $\mathrm{T}_{5}: 40 \%$ autoclave-treated wheat germ meal. SEM: Standard error of the mean. Different superscript letters within the same row mean significant differences $(\mathrm{p}<0.05)$

Table 6. Meat quality of New Zealand White rabbits (six weeks old) fed on untreated or autoclave-treated wheat germ meal

\begin{tabular}{lcccccc}
\hline Items & $\mathbf{T}_{\mathbf{1}}$ & $\mathbf{T}_{\mathbf{2}}$ & $\mathbf{T}_{\mathbf{3}}$ & $\mathbf{T}_{\mathbf{4}}$ & $\mathbf{T}_{\mathbf{5}}$ & $\mathbf{S E M}$ \\
\hline TAOC $(\mathrm{mM} / \mathrm{g})$ & $1.025^{\mathrm{ab}}$ & $0.3800^{\mathrm{ab}}$ & $0.465^{\mathrm{c}}$ & $0.9200^{\mathrm{b}}$ & $1.25^{\mathrm{a}}$ & 0.085 \\
MDA $(\mathrm{mg} / \mathrm{g})$ & $1.26^{\mathrm{d}}$ & $3.17^{\mathrm{a}}$ & $1.835^{\mathrm{c}}$ & $1.815^{\mathrm{c}}$ & $2.445^{\mathrm{b}}$ & 0.162 \\
Total cholesterol $(\mathrm{mg} / \mathrm{g})$ & $13.50^{\mathrm{c}}$ & $25.95^{\mathrm{a}}$ & $12.85^{\mathrm{c}}$ & $22.15^{\mathrm{b}}$ & $12.85^{\mathrm{c}}$ & 0.922 \\
\hline
\end{tabular}

TAOC: Total Antioxidant Capacity MDA: Malondialdehyde. $\mathrm{T}_{1}$ : control diet, $\mathrm{T}_{2:} 20 \%$ untreated wheat germ meal, $\mathrm{T}_{3}: 40 \%$ untreated wheat germ meal, $\mathrm{T}_{4}: 20 \%$ autoclave-treated wheat germ meal, $\mathrm{T}_{5}: 40 \%$ autoclave-treated wheat germ meal. Different superscript letters within the same row mean significant differences $(\mathrm{P}<0.05)$. SEM: Standard error of the mean.

Table 7. Blood constitutes of New Zealand White rabbits (six weeks old) with treated or untreated wheat germ meal

\begin{tabular}{lcccccc}
\hline Items & $\mathbf{T}_{\mathbf{1}}$ & $\mathbf{T}_{\mathbf{2}}$ & $\mathbf{T}_{\mathbf{3}}$ & $\mathbf{T}_{\mathbf{4}}$ & $\mathbf{T}_{\mathbf{5}}$ & SEM $^{\mathrm{a}}$ \\
\hline Total protein (g/ dl) & $5.44^{\mathrm{b}}$ & $6.10^{\mathrm{a}}$ & $5.59^{\mathrm{ab}}$ & $6.10^{\mathrm{a}}$ & $5.46^{\mathrm{b}}$ & 0.10 \\
Albumin (g/ dl) & 2.82 & 2.96 & 2.90 & 2.69 & 2.75 & 0.05 \\
Globulin (g/ dl) & $2.62^{\mathrm{b}}$ & $3.14^{\mathrm{a}}$ & $2.69^{\mathrm{b}}$ & $3.41^{\mathrm{a}}$ & $2.71^{\mathrm{b}}$ & 0.09 \\
Total cholesterol (g/ dl) & $83.75^{\mathrm{a}}$ & $57.90^{\mathrm{b}}$ & $75.17^{\mathrm{a}}$ & $58.16^{\mathrm{b}}$ & $53.56^{\mathrm{b}}$ & 3.46 \\
Total lipid (g/ dl) & $311.90^{\mathrm{a}}$ & $254.33^{\mathrm{b}}$ & $290.87^{\mathrm{a}}$ & $190.45^{\mathrm{c}}$ & $187.49^{\mathrm{c}}$ & 14.13 \\
ALT(U/ L) & 12.73 & 12.48 & 12.32 & 13.02 & 12.54 & 0.12 \\
AST(U/ L) & 16.22 & 15.01 & 14.70 & 15.44 & 15.02 & 0.25 \\
\hline
\end{tabular}

$\mathrm{T}_{1}$ : control diet, $\mathrm{T}_{2}: 20 \%$ untreated wheat germ meal, $\mathrm{T}_{3}: 40 \%$ untreated wheat germ meal, $\mathrm{T}_{4}: 20 \%$ autoclave-treated wheat germ meal, $\mathrm{T}_{5}: 40 \%$ autoclave-treated wheat germ meal. SEM: Standard error of the mean. Different superscript letters within the same row mean significant differences $(\mathrm{p}<0.05)$.

Table 8. Economic efficiency of New Zealand White rabbits (six weeks old) fed on diets with treated or untreated wheat germ meal

\begin{tabular}{lccccc}
\hline Items & $\mathbf{T}_{\mathbf{1}}$ & $\mathbf{T}_{\mathbf{2}}$ & $\mathbf{T}_{\mathbf{3}}$ & $\mathbf{T}_{\mathbf{4}}$ & $\mathbf{T}_{\mathbf{5}}$ \\
\hline Total weight gain (kg) & 1.498 & 1.363 & 1.200 & 1.467 & 1.292 \\
Price of 1kg body weight & 49 & 49 & 49 & 49 & 49 \\
Selling price/rabbit (LE) (A) & 73.40 & 66.78 & 58.85 & 71.88 & 63.31 \\
Total feed intake & 5.801 & 5.297 & 5.279 & 5.562 & 5.320 \\
Price/kg feed (LE) & 4.44 & 4.27 & 4.16 & 4.28 & 4.17 \\
Total feed cost/rabbit (LE) (B) $_{\text {Net revenue(LE) }}^{1}$ & 25.75 & 22.61 & 21.96 & 23.80 & 22.18 \\
Economic efficiency $^{2}$ & 47.65 & 44.17 & 36.89 & 48.08 & 41.13 \\
Relative economic efficiency $^{3}$ & 1.85 & 1.953 & 1.679 & 2.02 & 1.854 \\
\hline
\end{tabular}

$\mathrm{T}_{1}$ : control diet, $\mathrm{T}_{2}: 20 \%$ untreated wheat germ meal, $\mathrm{T}_{3}: 40 \%$ untreated wheat germ meal, $\mathrm{T}_{4}: 20 \%$ autoclave-treated wheat germ meal, $\mathrm{T}_{5}: 40 \%$ autoclave- treated wheat germ meal. LE: Egyptian pound. 1: Net revenue = A - B. 2: Economic efficiency = (A-B/B). 3: Relative Economic Efficiency= Economic efficiency of treatments other than the control/ Economic efficiency of the control group. 


\section{Chemical composition}

According to the results obtained in the present study, AWGM did not affect chemical composition of CP, CF, ash, and DE, while EE was decreased from 6.02 to $5.30 \%$ and lowered the anti-nutritional factor dry gluten by $50 \%$ and trypsin inhibitor activity by $62.4 \%$ compared to untreated WGM. Blair (2018) reported that WGM contains $250-300 \mathrm{~g} / \mathrm{kg}$ $\mathrm{CP}, 70-120 \mathrm{~g} / \mathrm{kg}$ crude fat and 30-60 g/kg CF. Moran and Summers (1967) reported that raw WGM contains $29 \% \mathrm{CP}$, $2.1 \% \mathrm{CF}$, and $10.3 \% \mathrm{EE}$, and the content did not influence antitrypsin activity. It was also found that autoclaving of raw WGM for 90 min did not influence CP, CF, EE, ash, and DE contents but antitrypsin activity was degraded. Creek et al. (1962) stated that autoclaving destroyed the activity of trypsin inhibitor and hemagglutinin factor. Also, Zhu et al. (2006) found that defatted WGM contains high amount of protein (34.9\%) and has a well-balanced amino acids profiles. Parrish and Bolt (1963) declared that raw WGM contain gluten as an anti-nutritional factor.

However, Bayley et al. (1968) found that raw WGM contained $29 \%$ CP, $3.4 \%$ CF, $10.3 \%$ EE, while after autoclaving for 45 or 20 min decreased CP contain from $29 \%$ to 28.6 and $28.7 \%$, respectively. Moreover, CF reduced from $3.4 \%$ to $2.9 \%$ and $\mathrm{EE}$ from $10.3 \%$ to $9.7 \%$. While, Ceve et al. (1968) found that the pelleting process increased the nutritive value of raw WGM, particularly in ME values.

\section{Growth performance}

Values of final body weight, BWG, and FCR almost close to the values found in rabbits fed on the low level (20\%) of treated or untreated WGM. However, at an increased untreated WGM in diet, significantly decreased final body weight and daily BWG and improved FCR. These results can be explained by Lawrence et al. (2002) who reported growth performance in pigs fed on diets containing wheat gluten at levels of 3, 6, 9 and $12 \%$ was not improved.

This decline in growth performance with increasing WGM level may be due to an increase in anti-proteolytic factor (trypsin inhibitor) which inhibit enzymatic digestion of proteins or other hemagglutinin factors (Creek and Vasaitis, 1962). Also, Moran and Summers (1967) found that anti trypsin activities were very high in raw WGM. Parrish and Bolt (1963) confirmed the impairment of growth rate, feed efficiency and fat absorption in chicks as a result of feeding raw WGM and the presence of gluten. In addition, Creek et al. (1961) reported that when chicks fed raw WGM led to a reduction in growth rate and feed efficiency, accompanied by hypertrophy of the liver and impairment of the absorption of fat and protein. In the present study, FI was not significantly affected by dietary treatments. Moran and Summers (1967) studied the effects of WGM autoclaved at $121{ }^{\circ} \mathrm{C}$ for 20 minutes then incorporating to chicken diets at the level of either $47 \%$ or $63.8 \%$ and found an improvement in these groups in growth performance and feed utilization compared with other groups fed WGM autoclaved for 90 min and control group. Also, Ceve et al. (1968) found that addition of AWGM (autoclaving at $118{ }^{\circ} \mathrm{C}$ for 20 or $45 \mathrm{~min}$ ) to broiler diet at a level of $33 \%$ improved BWG and FCR. Furthermore, Rafai et al. (2011) concluded that BWG of pigs was improved by $6 \%$ when they fed diet supplemented with fermented wheat germ extract at the level of $1 \mathrm{~g} / \mathrm{kg}$ of diet compared with the control group. Also, Ellakany et al. (2017) documented that incorporation of fermented wheat germ extract with Saccharomyces cerevisiae at levels of $0.5,1.5$ and $3 \mathrm{~g} / \mathrm{kg}$ of diet increased body weight significantly in broilers, especially at the dose $3 \mathrm{~g} k \mathrm{~g}$ of diet.

\section{Digestibility coefficient}

The effect of experimental diets on digestion coefficient and nutritive values were in agreement with Moran and Summers (1967) who found denaturation of raw WGM increased digestibility because of decreased resistance to enzymatic degradation and destruction of toxic factors. Also, Nesheim et al. (1962) stated that fat absorption of raw soybean meal in chickens was improved by heat treatment. Moreover, similar processing of raw soybean enhanced meal digestibility from 64 to $88 \%$ in the cockerel (Nitsan, 1965) and from 54 to 89\% for the laying hen (Nesheim and Garlich, 1966). Contrarily, Ceve et al. (1968) found that addition of $33 \%$ AWGM at $118{ }^{\circ} \mathrm{C}$ for 20 or 45 min) to broiler diet were significantly improved metabolizable energy and fat digestibility compared to those fed on raw WGM. Suliman et al. (2015) found an insignificant decrease in terms of digestion coefficients of CP, CF, and NFE when rabbits fed diets containing chemically and biologically treated castor meal at $20 \%$ as replacement of soybean meal.

\section{Carcass characteristics}

The results obtained in the current study was consistent with Duwa et al. (2014) who reported rabbit fed with 30\% roasted sunflower seed meal indicated highest average values in terms of slaughter weight, carcass weight and dressing percentage in comparison to groups received 10, $20 \%$ roasted sunflower seed meal and control group. While, there was no significant difference in liver, kidney, lung, and heart among the treatment groups. Gasmi et al. (2007) found that liver weight was not affected when rabbits fed with rapeseed meal (canola seed meal) replaced up to14\% dietary soybean meal. On the other hand, Leeuw et al. (2009) detected no difference in carcass weight and dressing percentage when using 75 or $100 \%$ maize germ meal in steers diets. Ellakany et al. (2017) found that combination of fermented wheat 
germ extract with Saccharomyces cerevisiae at doses of $0.5,1.5$ and $3 \mathrm{~g} / \mathrm{kg}$ of diet significantly increased the percentage of intestinal weight and decreased the weight of the liver and total body fat in broilers.

\section{Meat quality}

The supplementation of natural antioxidant in feed decreases lipid peroxidation and improves stability of meat. Consistently, Gnanasampandam and Zayas (2007) found that the addition of $7 \%$ wheat germ protein flour decreased the fat content in frankfurters. On the other hand, Arshad et al. (2013) found that combination of wheat germ oil and lipoic acid improves the quality of the broiler meat. Arshed et al. (2017) reported that nuggets were made from the leg meat of chickens fed with combination of $\alpha$-lipoic acid $(150 \mathrm{mg} / \mathrm{kg})$ and wheat germ oil (200 $\mathrm{mg} / \mathrm{kg})$ showed maximum antioxidant power as well as stability during storage.

\section{Blood constituents}

In the present experiment, the results of blood constituents were in agreement with Ellakany et al. (2017) who found the incorporation of fermented wheat germ extract with Saccharomyces cerevisiae at rates of $0.5,1.5 \mathrm{and} 3 \mathrm{~g} / \mathrm{kg}$ diet significantly decreased triglyceride level in blood. A significant decrease in AST concentration was observed at a dose of $1.5 \mathrm{~g} / / \mathrm{kg}$ of diet, while both doses of 1.5 and $3 \mathrm{~g} / \mathrm{kg}$ of diet decreased significantly ALT level in the blood. In this respect, Louis et al. (1991) reported that blood lipid was decreased when adding small quantities of raw and defatted wheat germ in the rat diet.

\section{Economic efficiency}

Rabbit fed on the diets contained untreated or treated WGM at level of $20 \%$ had higher economic return than control diets. These results were in agreement with Leeuw et al. (2009) who found lower feed cost when using $100 \%$ defatted maize germ meal in steers' diets.

\section{CONCLUSION}

It is concluded that untreated or autoclave-treated WGM can be used up to $20 \%$ in growing rabbit diets as a substitution for soybean meal protein without adverse effects in rabbit performance and an improvement in economic efficiency compared to those fed with $40 \%$ untreated or autoclave-treated WGM.

\section{DECLARATIONS}

\section{Author's contributions}

Dr. Walaa A. Salama designed the work and drafted the manuscript. Dr. Amira M. Refaie performed the statistical analysis, tabulation of the experimental data and chemical analysis. Dr. Hamdy F. Amin participated in review the manuscript and Dr. Lamiaa F. Abdel Mawla performed the practical part of the experiment.

\section{Competing interests}

The authors have declared that no competing interests exist.

\section{REFERENCES}

AOAC (2000). Official Methods of Analysis, 17th Edition. Washington D.C., pp. 55-101.

Arshad MS, Anjum FM, Khan MI and shahid M (2013). Wheat germ oil enrichment in broiler feed with œ lipoic acid to enhance the antioxidant potential and lipid stability of meat. Lipids Health Disease, 12:164-191. DOI: https://doi.org/10.1186/1476-511X-12-164.

Arshad MS, Lmran A, Nadeem MT, Sohaib M, Saeed F, Anjum FM, Kown, JH and Hussain S (2017). Enhancing the quality and lipid stability of chicken nuggets using natural antioxidants. Lipids Health Disease, 16:108. DOI: https://doi.org/10.1186/s 12944-017-0496-4.

Barton--Wright EC and Monr NT (1946). The microbiological assay of amino-acids, II. The distribution of amino-acids in the wheat grain. Analyst, 71:278-282. DOI: http://dx.doi.org/10.1039/an9467100278

Bayley HS, Summers, JD and slinger SJ (1968). Effect of heat treatment on the metabolizable energy value of wheat germ meal and other wheat milling by products. Cereal Chemistry, 45:557.

Biasco A and Ouhayoun J (1996). Harmonization of criteria and terminology in rabbit meat research. World Rabbit Science, 4: 93-99. DOI: https://doi.org/10.4995/wrs 1996.278.

Blair R (2018). Nutrition and feeding of organic poultry. Approved ingredients for organic diets, 2nd Edition. CABI, UK, p. 74. DOI: http://dx.doi.org/10.1079/9781845934064.0000 
Brandolini Aand Hidalgo A (2012). Wheat germ: not only a by-product. International Journal Food Science Nutrient, 63 (1):71-74. DOI: https://doi.org/10.3109/09637486.2011.633898

Ceve NAG, Slinger S and Summers JD (1968). Significance of processing wheat germ meal for growing chicks. Canadian Journal. Animal Science, 48:199-205. DOI: https://doi.org/10.4141/cjas 68-025

Cheeke PR (1987). Rabbit feeding and nutrition. Academic Press, Orlando, Florida, USA, p. 376

Creek RD and Vasaitis V (1962). Detection of an anti-proteolytic substance in raw wheat germ. Poultry Science, 41: 1351-1352.

Creek RD, Vasaitis V and Schumaier G (1961). The improvement of the nutritive value of raw wheat germ meal by autoclaving. Poultry Science, 40:822-824. DOI: https://doi.org/10.3382/ps 0400822.

Creek RD, Vasaitis V, Pollard WO and Schumaier G (1962). Evidence for the presence of a thermolabile growth inhibitor in raw wheat germ. Poultry Science, 41: 901-904.

De Vasconcelos MC, Bennett R, Castro C, Cardoso P, Saavedra MJ and Rosa EA (2013). Study of composition, stabilization and processing of wheat germ and maize industrial by-products. Industrial Crops and Products, 42: 292298. DOI: https://doi.org/10.1016/j. indcrop.2012.06 .007

Duncan DB (1955). Multiple Range and Multiple F-Test. Biometrics, 11:1-42.

Duwa AY, Girgirl AD and Igwebuike JU (2014). The effect of feeding graded levels of roasted sunflower (Hellanthus Annuus L.) seed meal on weaner rabbits. Online Journal of Animal and Feed Research, 4 (5):107- 112. http://www.ojafr.ir/main/attachments/article/106/Online\%20J.\%20Anim.\%20Feed\%20Res.,\%204(5)\%20107112,\%202014.pdf

Egyptian Ministry of Agriculture (2014). Study of important indicator of the agriculture statistics.

Ellakany H, El-Sayed A, Soliman F and Elbestawy A (2017). The effect of fermented wheat germ extract on biochemical, physiological and performance of broiler chickens. Alexandria Journal Veterinary Sciences, 55(2):9197. DOI: http://dx.doi.org/10.5455/ajvs. 280407

Elliott DC, Orth RJ, GAO J, Werpy TA, Eakin DE and Schmidt AJ (2002). Bio refinery concept development based on wheat flour milling. Fuel Chemistry Division Preprints, 47: 361-362.

Feed composition for animal and poultry feed stuff used in Egypt (2001). Technical Bulletin No.1, Central lab for feed and food. Ministry of Agriculture. Egypt.

Gasmi B, Hedi M El Hichi and Faiza K (2009). Feeding rapeseed meal to rabbits: Digestibility, performance and carcass characteristics. Asian journal of animal and veterinary advances, 2(1):38-41. DOI: https://doi.org/10.3923/ajava.2007.38.41

Gerald F, Combs JR and James P McClung (2017). Fundamental Aspects in Nutrition and Health. The Vitamins, Vitamin E, 5th Edition. Academic Press, pp.207-242. DOI: https://doi.org/10.1016/B978-0-12-802965-7.00008-3

Gnanasambandam R and Zayas JF (2007). Quality characteristics of meat batters and frankfurters containing wheat germ protein flour. Journal of Food Quality, 17 (2): 129-142. DOI: https://doi.org/10.1111/j. 1745- 4557.1994.tb00138.x.

Hafez LO, Ali FA, El-Ghoneimy AA and Abdel-Aziz MI (2019). Nephro-Protective effect of wheat germ oil on gentamicin-induced acute nephrotoxicity in wistar albino rat. International Journal of Veterinary Sciences, 2 (1): 51 67.

Haraszi R, Chassaigne H, Maquet and Ulberth F (2011). Analytical methods for detection of gluten in food-method developments in support of food labeling legislation. Journal AOAC international, 94 (4): 1006-1025.

Lawrence KR, Goodband RD, Tokach MD, Nelssen, J L, Dritz SS, De Rouchey JM, Hastad CW, Hanni SM, Barker MR and James BW (2002). Evaluation of wheat gluten and spray-dried animal plasma on growth performance of nursery pigs. Kansas Agricultural Experiment Station Research Reports, 10: 88-93. DOI: https://doi.org/10.4148/23785977.6762.

Leeuw KJ, Meissner HH and phallic D (2009). A comparison between hominy chop and defatted maize germ meals as the main energy source in diets of feedlot steers. South African Journal of Animal Science, 39 (1): 126- 129. DOI: https://doi.org/10.4314/sajasv39i1.61214.

Louis C, Borel B, Martine A and Senft M (1991). Effects of increasing levels of raw or defatted wheat germ on liver, feces and plasma lipids and lipoproteins in the rat. Nutrition Research, 11(8): 907-916. DOI: https://doi.org/10.1016/S0271-5317(05)80618-9.

Makkar HPS, Siddhuraju P and Becker K (2008). Molecular biotechnology: Plant secondary metabolites. Molecular Biotechnology, 38(2):185.

Moran ET and Summers JD (1967). The effect of toasting and autoclaving on the quality of wheat germ meal protein for the growing chick. Cereal Science, 1(2):117.

Nesheim MC and Garlich JD (1966). Digestibility of unheated soy bean meal for laying hens. Journal Nutrition, 88:187192. DOI: https://doi.org/10.1093/jn 88.2.187.

Nesheim MC, Garlich JD and Hopkins DT (1962). Studies on the effect of raw soy bean meal on fat absorption in young chicks. Journal Nutrition, 78:89-94. DOI: https://doi.org/10.1093/jn 78.1.89. 
Nitsan Z (1965). The effect of heating soy bean meal on the apparent digestibility and metabolism of protein, methionine and lysine by cockerels. Poultry Science, 44:1036-104 3. DOI: https://doi.org/10.3382/ps. 441036.

Parrish JA and Bolt RJ (1963). Effect of raw wheat germ meal on the nutrition of the chicken. Nature, 199: 398-399.

Rafai P, Papp Z, Jakab L, Tuboly T, Jurkovich V and Brydl E (2011). The effect of fermented wheat germ extract on production parameters and immune status of growing pigs. Journal Animal and Feed Science, 20:36-46. DOI: https://doi.org/10.22358jafs. 66156

Saleh H (2016). Modulatory effects of wheat germ oil on intestinal oxidative stress and DNA damage induced by carbon tetrachloride in mice. Journal of Applied Pharmaceutical Science, 6 (12): 67-74. http://www.japsonline.com/admin/php/uploads/2084_pdf.pdf

SAS (2004). User's Guide:. Statistic. Version 9. Cary, N.C. USA.

Schneider B.H. and W.P. Flatt (1975). The Evaluation of feed through Digestibility experiments. University of Georgia Press Athens, Georgia, USA, pp. 423.

Suliman, MA, Salama WA, Matari RIM and El-Shora MA (2015). Productive performance of New Zealand white growing rabbits fed on diets containing different levels of treated castor meal. Egyptian Journal Nutrition and Feeds, 18 (2): 361-370.

Zhu KX, Zhou HM and Qian HF (2006). Proteins Extracted from Defatted Wheat Germ: Nutritional and Structural Properties. Cereal Chemistry, 83: 69-75. DOI: https://doi.org/10.1094/cc-83-0069 